This document was prepared in conjunction with work accomplished under Contract No. DE-AC09-96SR18500 with the U. S. Department of Energy.

\title{
DISCLAIMER
}

This report was prepared as an account of work sponsored by an agency of the United States Government. Neither the United States Government nor any agency thereof, nor any of their employees, makes any warranty, express or implied, or assumes any legal liability or responsibility for the accuracy, completeness, or usefulness of any information, apparatus, product or process disclosed, or represents that its use would not infringe privately owned rights. Reference herein to any specific commercial product, process or service by trade name, trademark, manufacturer, or otherwise does not necessarily constitute or imply its endorsement, recommendation, or favoring by the United States Government or any agency thereof. The views and opinions of authors expressed herein do not necessarily state or reflect those of the United States Government or any agency thereof.

This report has been reproduced directly from the best available copy.

Available for sale to the public, in paper, from: U.S. Department of Commerce, National Technical Information Service, 5285 Port Royal Road, Springfield, VA 22161, phone: (800) 553-6847, fax: (703) 605-6900

email: orders@ntis.fedworld.gov

online ordering: http://www.ntis.gov/help/index.asp

Available electronically at http://www.osti.gov/bridge

Available for a processing fee to U.S. Department of Energy and its contractors, in paper, from: U.S. Department of Energy, Office of Scientific and Technical Information, P.O. Box 62, Oak Ridge, TN 37831-0062,

phone: (865)576-8401,

fax: (865)576-5728

email: $\underline{\text { reports@ adonis.osti.gov }}$ 
WSRC-MS-2003-00301

\section{SURVEY OF PACKAGING REQUIREMENTS FOR THE TRANSPORT OF HIGHLY HAZARDOUS MATERIALS}

\author{
Daniel R. Leduc \\ Westinghouse Savannah River Co. \\ Aiken, South Carolina, 29808 \\ (803) 725-5261, dan.leduc@srs.gov
}

\author{
Allen C. Smith \\ Westinghouse Savannah River Co. \\ Aiken, South Carolina, 29808 \\ (803) 725-2943, allen.smith@srs.gov
}

\begin{abstract}
Among hazardous materials those which are most dangerous fall into three categories: chemical, biological, and radioactive. The DOT hazard classes for these three categories are Hazard Class 2.3 (poisonous gasses) and 6.1 (toxic substances) for chemical hazards, Hazard Class 6.2 (infectious substances) for biological hazards and Hazard Class 7 for radioactive material (RAM) hazards. The packaging requirements for chemical and biological hazards are outlined and compared with RAM packaging requirements. RAM packages are found to be able to withstand much more severe performance tests than packages for other, more lethal hazards.
\end{abstract}

\section{Background}

The degree of danger for hazardous materials ranges from negligible to highly lethal. Transportation regulations provide a graded means of transporting such material in which the packaging requirements are proportional to the level of danger. The most hazardous materials fall into three categories: chemical, biological, and radioactive (or nuclear). Hazardous substances are divided into Hazard Classes, according to the nature of the hazard. For example, explosives are Hazard Class 1 (HC-1) materials. The classes are subdivided into more specific hazard types. This review addresses highly hazardous materials, which can be divided into three categories: chemical (Classes 2.3 and 6.1), biological (Class 6.2), and radioactive (Class 7). Explosives and lesser hazards, such as non-poisonous gasses (HC-2), flammable liquids (HC-
3), flammable solids (HC-4), and Oxidizers (HC-5) are not addressed here.

Packages for the Transport of Chemical Hazards Gasses

Hazard Class 2 (HC-2) consists of hazardous materials which are a gas at $20^{\circ} \mathrm{C}\left(68^{\circ} \mathrm{F}\right)$ and $101.3 \mathrm{kpa}(14.7 \mathrm{psi})$. HC-2 is divided into three-divisions: Division 2.1

(flammable gasses), Division 2.2 (non-flammable, non poisonous compressed gasses), and Division 2.3 (gasses that are poisonous by inhalation). Gasses poisonous by inhalation are further subdivided into four hazard zones depending on the $\mathrm{LC}_{50}$ value of the gas per Figure 10. The $\mathrm{LC}_{50}$ value for acute toxicity by inhalation means that concentration of vapor mist or dust which administered by continuous inhalation for one hour to both male and female young adult albino rats, causes death within 14 days in half of the animals tested per 49 CFR 173.132.

Most poisonous gasses (Division 2.3 materials in the table 49 CFR 172.101) are required to be in cylinders, which must meet the requirements of 49 CFR 173.40. Hazard Zone A poisonous gasses, which have the lowest $\mathrm{LC}_{50}$ values and are the most dangerous are further restricted to a small subset of specification cylinders (DOT-3A, 3AA, 3AL, and 3E specification cylinders) per 173.192. These cylinders must have a water capacity of no more than 125 pounds or about 15 gallons.

Although such a cylinder would be appropriate for many poisonous and flammable gasses, Table 172.101 should be consulted to determine special packaging needs for 
particular Division 1 and 3 gasses. Many chemical warfare agents such as Sarin, VX, and Mustard gas are liquid at room temperature. They have a vapor pressure high enough to evolve significant vapors, however, since they are a liquid at room temperature they are regulated as Hazard Class 6.1 materials.

Although DOT cylinders provide protection from large pressure differences, they are not designed specifically to withstand impacts and generally have no design features to enhance leak testing. Even for Phosgene gas, which is considered one of the most poisonous, the leak test consists of submerging the vessel in water and visually looking for bubbles over a thirty minute period per 173.192. Bubble testing has a sensitivity of only about $10^{-3} \mathrm{ref} \mathrm{cm}^{3} / \mathrm{s}$ whereas radioactive material packaging can in many cases be tested to sensitivities below $10^{-7}$ ref $\mathrm{cm}^{3} / \mathrm{s}$.

\section{Packages for the Transport of Chemical Hazards - Poisonous Material}

Poisonous materials encompass a large variety of substances but are divided into two divisions, Division 6.1 (chemical poisons) and Division 6.2 (infectious substances). Infectious Substance Packaging is described in Section 3.2 of this report.

Division 6.1 poisonous materials are defined as those materials, other than a gas, which are known to be so toxic to humans as to afford a hazard to health during transportation. Poisonous materials are divided into those substances with an inhalation toxicity, oral toxicity, or dermal toxicity.

The $\mathrm{LC}_{50}$ value for inhalation toxicity already defined in section 3.1.1. has the units of $\mathrm{mg} / \mathrm{L}$ for particulate and $\mathrm{mL} / \mathrm{m}^{3}$ for gasses and liquid vapors. The $\mathrm{LD}_{50}$ values for oral and dermal toxicity are defined similarly but as a quantity or dose instead of a concentration. For oral toxicity it is the quantity per unit body mass of material administered orally to both male and female young adult albino rats which causes death within 14 days in half the animals tested. The units for oral toxicity are $\mathrm{mg}$ of material per $\mathrm{kg}$ of body mass. The dermal toxicity $\mathrm{LD}_{50}$ is defined similarly and has the same units, except that the dose is absorbed through a shaved portion of the rat's skin over a 24 hour period.

For liquids, the $\mathrm{LC}_{50}$ value along with the volatility (the relative rate of evaporation to the vapor state) determines both the packaging group and the hazard zone as shown in Figure 1 which is taken directly from 173.133. Hazard zones are not specified for solids. Unless otherwise specified in Table 172.101, for solids and routes of administration other than inhalation by vapors, the packaging group is assigned by Table 1 , which is taken from 173.133.

In general, the lower the $\mathrm{LC}_{50}$ value and the higher the volatility of a particular liquid, the higher the performance level of the package required.

Liquids with the lowest $\mathrm{LC}_{50}$ values and the highest volatility are classed as PG-I, Hazard Zone A, and must be packaged according to 173.226 .

\begin{tabular}{|c|c|c|c|}
\hline $\begin{array}{c}\text { Packing } \\
\text { Group }\end{array}$ & $\begin{array}{c}\text { Oral toxicity } \\
\mathrm{LD}_{50} \\
(\mathrm{mg} / \mathrm{kg})\end{array}$ & $\begin{array}{c}\text { Dermal } \\
\text { toxicity } \\
\mathrm{LD}_{50} \\
(\mathrm{mg} / \mathrm{kg})\end{array}$ & $\begin{array}{c}\text { Inhalation } \\
\text { toxicity by } \\
\text { dusts and } \\
\text { mists } \mathrm{LC}_{50} \\
(\mathrm{mg} / \mathrm{L})\end{array}$ \\
\hline I & $\leq 5$ & $\leq 40$ & $\leq 0.5$ \\
\hline II & $>5, \leq 50$ & $>40, \leq 200$ & $>0.5, \leq 2$ \\
\hline III & $\begin{array}{c}\text { Solids: }>50, \\
\leq 200 ; \\
\text { Liquids: } \\
>50, \leq 500\end{array}$ & $>200, \leq$ & $>2, \leq 10$ \\
\hline
\end{tabular}

Table 1.

PG Determination For Oral and Dermal Toxicity and Dust Concentrations

The most common packages for the most severe poisonous-by-inhalation materials are combination packages consisting of inner and outer containers. The outermost container of a combination package can be constructed of a wide variety of materials, the least expensive of which is a fiberboard. The inner packaging system must consist of two parts: an impact resistant receptacle of glass, earthenware, plastic or metal securely cushioned with a non-reactive, absorbent material packaged in a leak-tight packaging of metal or plastic. The standard for this leak tightness is for visual leakage only and does not equate to the much stricter leak-tight definition for radioactive packaging.

The inner packaging system, the bottle and can must meet the Packaging Group I performance tests described above without the benefit of the outer packaging. For larger quantities of the most poisonous substances (up to 58 gallons), containers that employ a drum within a drum system are allowed. Specifically a closed head drum of steel, aluminum, plastic, non-ferrous metal or a composite 
of plastic and steel $(1 \mathrm{~A} 1,1 \mathrm{~B} 1,1 \mathrm{H} 1,1 \mathrm{~N} 1$ or $6 \mathrm{HA} 1$ respectively ) inside an outer open head drum of steel or plastic (1A2 or $1 \mathrm{H} 2)$. These packages are assembled by combining a closed head drums with an open head drum the meets the thickness requirements described in 173.226

Specification cylinders are also allowed for PG I, Hazard Zone A, Class 6.1 materials. A few companies, such as Columbiana Boiler, manufacture cylinders specifically to the 4BW cylinder specification for materials that are Poisonous by Inhalation (PIH).

Under the Code of Federal Regulations, only the Department of Defense is allowed to ship chemical weapons and components. DOD has obtained DOT approval to transport Recovered Chemical Warfare Material (RCWM) which includes V and G series nerve agents and $\mathrm{H}$ and $\mathrm{HN}$ series blister agents in containers designed and built to DOD standards.

These containers include Single Round Containers (SRCs) and Multiple Round Containers (MRCs) designed and fabricated by the Defense Ammunition Center (DAC). These containers are packaged inside wooden boxes, like the ones shown in the background of Figure 2, for impact absorption.

These containers have been tested to a composite of tests taken from radioactive material packaging, PG-I package testing, and transportation environment testing. Some containers have been drop tested from 40 feet with the wooden overpack in place. The container is, as a minimum, dropped from the required PG-I drop height without the wooden overpack. The containers are also subjected to side and vertical low frequency shake testing as well as vehicle tests involving wash-boarded roads and a panic stop test.

The leak test specified for most of the smaller containers built by the DAC is a helium leak test as described in Appendix B of 49 CFR 178 where the package is filled with helium and placed in a testing chamber capable of being evacuated. This method provides an extremely sensitive leak test with detection to at least $1 \times 10^{-6} \mathrm{std}$ $\mathrm{cc} / \mathrm{sec}$ of helium or $3.7 \times 10^{-7} \mathrm{std} \mathrm{cc} / \mathrm{sec}$ of air, comparable to leak test requirements for many RAM packages.

The materials used in the construction of MRC and SRC containers include common grades of low carbon steel for packages used on military reservations and stainless steel for packages used in commerce. The coating for carbonsteel components on the inside of the containment consists of a common primer indicating that the corrosive properties of the agents are not overly aggressive. Flange face seating surfaces are not painted but are treated with a non-petroleum based rust preventative, which is compatible with the contained agents. The O-ring seals used on these containers are composed of butyl synthetic.

For transportation of larger quantities of chemical warfare agents on military reservations, the DOD has developed another set of packages, outside of DOT regulations. These packages were developed by Sandia National Laboratory (SNL), which has extensive experience in developing and testing containers for the transport of radioactive materials.

For the development of these chemical agent packages, Sandia used safety criteria modeled after the International Atomic Energy Agency (IAEA) hypothetical accident sequence for radioactive material transport packages. The use of IAEA standards reflects the lack of DOT safety standards for containers with large closures that contain the most poisonous Hazard Class 6.1, Hazard Zone A and B materials. Examples of large overpacks for transport of these agents are shown in Figures 3 and 4.

\section{Packages for the Transport of Infectious Substances}

An infectious substance is defined in DOT regulation 49 CFR173.134 as "a viable microorganism, or its toxin that causes or may cause disease in humans or animals." This definition includes those agents listed in the Department of Health and Human Services (HHS) regulations, 42 CFR 72.1, and any other agent that causes or may cause severe, disabling or fatal disease.

Infectious substances are Class 6, Division 6.2, hazardous materials regulated under the HMR. Infectious substance and etiologic agent are used synonymously in this report.

The minimum HHS packaging requirements (excluding labeling) for infectious substances are specified in 42 CFR 72.3. In summary, the HHS regulations address volumes less than or equal to $50 \mathrm{ml}$, volumes greater than $50 \mathrm{ml}$, and the use of dry ice.

For volumes less than or equal to $50 \mathrm{ml}$, HHS requires a watertight primary and secondary container, nonparticulate absorbent between these containers, with the nested primary and secondary containers enclosed in an outer shipping container constructed of corrugated fiberboard, cardboard, wood, or other material of equivalent strength. 
For volumes greater than $50 \mathrm{ml}$, the same requirements apply, plus the following additional requirements. Shock absorbent material is required between the secondary container and shipping container. The maximum volume placed in a secondary container is $1,000 \mathrm{ml}$, the maximum volume in a single shipping container is $4,000 \mathrm{ml}$ or about 1 gallon per Title 42 Chapter I Part 72.3 (b).

If used as a refrigerant, dry ice must be placed outside the secondary container(s). Shock absorbent material shall be placed so that the secondary container does not become loose inside the shipping container as the dry ice sublimates.

DOT regulation of infectious substances is intended to supplement HHS regulations. DOT packaging standards and test requirements are specified in 49 CFR 173.196 and 49 CFR 178.609 respectively. DOT requirements are summarized in the following discussion.

Infectious substances require watertight primary and secondary containers. The primary or secondary container must be capable of withstanding, without leakage, an internal pressure of $95 \mathrm{kPa}(14 \mathrm{psi})$ at temperatures from $-40 \mathrm{~F}$ to $131 \mathrm{~F}$. The smallest external dimension of the outer shipping container must be at least $100 \mathrm{~mm}$ (3.9 in.). Infectious substance packaging must be capable of passing, without leakage from the primary

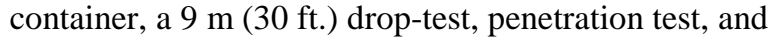
vibration standard. A typical infectious-substance packaging configuration is shown in Figure 5.

Packaging for infectious substances and etiological agents must be certified. This takes the form of a report from an independent testing laboratory confirming that the package meets the performance test requirements. Packages for ground and air shipments of infectious substances are commercially available.

At least one of the two water tight receptacles of an Infectious Substance package must be capable of withstanding, without leakage, an internal pressure which produces a pressure differential of not less than $95 \mathrm{kPa}$ (14 psi) and temperatures in the range of $-40^{\circ} \mathrm{C}$ to $55^{\circ} \mathrm{C}(-$ $40^{\circ} \mathrm{F}$ to $\left.+131^{\circ} \mathrm{F}\right)$. In many cases the pressure tested component is a screw top lid plastic bottle. In other cases, it may be the test tubes that are pressure tested.

Plastic bottles subjected to almost a full atmosphere as described above will deform noticeably. Most of these bottles are small given the 1 gallon limit. Vessels of plastic construction would encounter structural problems at the required test pressure if they were allowed to exceed the one gallon capacity.

The Hazardous Material Regulations for the Transportation of Infectious Substances are currently being revised (Federal Register, Volume 67, No. 157). The new regulation provides a specific exception for forensic evidence transported by government agencies. The Exception will be in 49CFR173.134 (b) 12 and requires only that the packages used for transport of forensic evidence containing infectious substances be in accordance with 173.24 , be tested as required by 178.609 and labeled in accordance with 29CFR1910.1030(g)(1)(I).

The new regulations within Title 49 are silent on the 1 gallon restriction contained in Title 42 . The new rule became law on February $14^{\text {th }} 2003$ but it is unclear whether larger purpose built containers will become commercially available since only forensic evidence transported by government agencies would be able to utilize the new exception.

With regard to package performance, all the radioactive material packages described below, except for the Type A containers, exceed the testing criteria for infectious packaging outlined in 49 CFR 173.196 and 178.609. The Type B packages described below are all more robust than typical infectious substances packages.

\section{Packages for the Transport of Radioactive Materials}

Radioactive materials can affect human health by destroying cells or altering cell functions. The International Commission on Radiation Protection (ICRP) has established a "Q system" for quantifying the effects of different forms of radiation on the human body. This system quantifies the dose received by all the potential pathways to the body including external gamma and beta dose, dose from skin contamination and ingestion, inhalation dose, and the dose from submersion in gaseous clouds of isotopes.

The dose received is really what the ICRP calls dose equivalence which is measured in Roentgen Equivalent Man (REM). This "rem" scale is intended to be a common measure of injury from all radiation such that a 1 rem dose from a particular radionuclide causes the same amount of injury to humans as a 1 rem dose from any other radionuclide. The amount of radioactivity, on the other hand, is measured in curies which relates to the disintegration rate of the radioactive material. 
The ICRP has normalized all radioactive materials by evaluating the amount of each radionuclide required to give an individual a 5 rem dose when all the possible pathways described in the $\mathrm{Q}$ system are considered. The result has been adopted by the Code of Federal

Regulations as the $\mathrm{A}_{2}$ values listed in Table $173.435^{*}$. The $\mathrm{A}_{2}$ values listed in the table are expressed in tera bequerals or curies and represent the amount of each radionuclide required to give an individual a 5 rem dose when all possible pathways are considered.

When the material contains a combination of radionuclides, the $\mathrm{A}_{2}$ value for the mixture is determined by the mass fraction of each radionuclide in the mixture and its $\mathrm{A}_{2}$ value.

Because all radionuclides are normalized by the ICRP process, radioactive hazardous materials are not further subdivided into divisions based on different hazards such as used those for chemical hazards. Radioactive packaging is divided into those packages containing an $\mathrm{A}_{2}$ or less (Type A packaging) and those packages containing more than an $A_{2}$ (Type $B$ packaging).

Type A radioactive packaging is similar to other DOT performance based packaging with respect to conditions for use and administrative controls. These packages are required to meet the tests and standards outlined in Subpart I of 49CFR 173. Packages meeting these standards can generally be used to transport any radionuclide as long as the quantity remains at or below an $A_{2}$. Type $B$ packaging, which may contain thousands of $A_{2 s}$ are usually only certified for specific radionuclides in a specific form.

Type $\mathrm{B}$ radioactive packaging is the only hazardous material packaging required to function under designated accident conditions. These are a sequence of accident tests on the same package sample. The test sequence starts with a free drop from thirty (30) feet followed by a crush test involving an 1,100 pound plate dropped from 30 feet (only required for packages less than 1,100 pounds with a density less than water). This is followed by a puncture test (a drop from one meter onto a six inch diameter steel bar) followed by the package being engulfed in a $1475^{\circ} \mathrm{F}$ fire for 30 minutes. The final test is immersion in 50 feet of water. This final test can be performed on an undamaged package and is not required to be part of the test sequence. The package must provide

\footnotetext{
* A values are for encapsulated or special form radioactive material.
} 1 containment, shielding and sub-criticality following these tests.

Type B packaging for radioactive materials have the most extensive regulatory requirements of any hazardous material packaging. Each individual package design is required to have a Safety Analysis Report for Packaging (SARP) which documents the performance of the package through testing and analysis. The SARP must be reviewed by a competent authority from the Nuclear Regulatory Commission (NRC), the Department of Energy (DOE), or the Department of Transportation depending on the intended use of the package. If acceptable, one of these organizations then issues a Certificate of Compliance (COC) for the package.

Unlike other hazardous material packaging, the COC describes specific radioactive contents, which are usually very restrictive. Contents may by restricted to only certain radionuclides with specific curie and gram limits as well as limitations on the mixture of radionuclides. These restrictions are often the result of conservative assumptions in the SARP analyses due to shielding, containment and criticality issues. Often the COC will restrict the contents to certain radionuclides because criticality and shielding analyses have not been performed for other radionuclides. Type $\mathrm{B}$ radioactive packages approved by DOE and NRC require each intended package user to register with them prior to use of the package.

Even though the certification process is specific to individual packages, radioactive packages usually have similar construction. Typically, they consist of one or more stainless steel containment vessels surrounded by impact absorbing material and an outer skin, also composed of stainless steel. The closure seal can vary but is usually composed of an elastomer O-ring although some packages use a soft metal gasket. Following loading and securing of the lid, RAM packages must be subjected to post load leak tests to confirm that the necessary containment standard is met.

\section{Discussion and Conclusions}

The common factor for packages for chemical, biological and radiological materials is containment of the hazardous material. Each category of package must withstand performance tests specified by 49 CFR and other regulations. The testing requirements are graded, so that the higher the hazard, the more rigorous the test requirements. An example of this graded approach is the division of RAM packages into Type A and Type B 
packages. Experience has shown these tests to be adequate to protect the public under almost all conditions which might be encountered in commerce.

In addition to containment, radioactive materials packages must also provide shielding and maintain subcriticality, and must continue to do so following an accident. Although the standard of package integrity required by the Regulations, in terms of extent of performance tests, is generally comparable, radioactive materials packages are, in practice, much more robust than those for chemical or biological hazards. It is ironic that the so much attention should be focused on the hazard of radioactive materials packages when the health hazard of the other highly hazardous materials is so great, and the packages used to transport them are less robust.

\section{References}

1. United States Code of Federal Regulations, Title 49, Transportation.

2. American National Standard for Radioactive Materials - Leakage Tests on Packages for Shipment, ANSI N14.51997.

3. Standard Specification for Testing of Hazardous Materials Packagings, American Society for Testing and Materials, ASTM D4919 - 1997.

4. McAllaster, M. E., Pierce, J. D., and Hohnstreiter, G. F., DATE, "The Development of an Enhanced Container for On-Site Transport of Chemical Munitions",

5. United States Code of Federal Regulations, Title 10, Energy 
WSRC-MS-2003-00301

\section{Figure 1 \\ Inhalation Toxicity: Packing Group and Hazard Zone Borderlines}

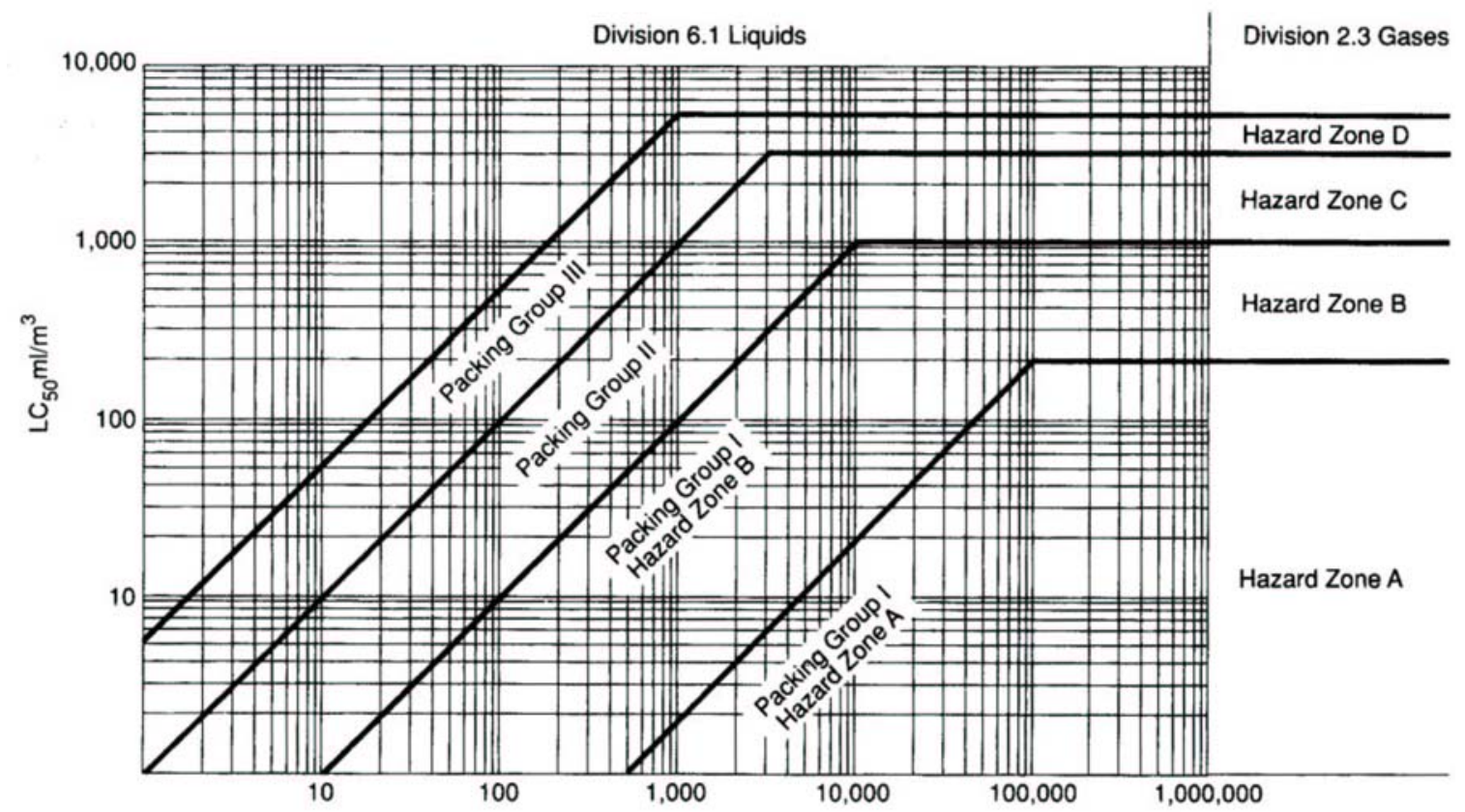

Figure 1. Chart for Determining Hazard Zone of Liquids and Gasses.

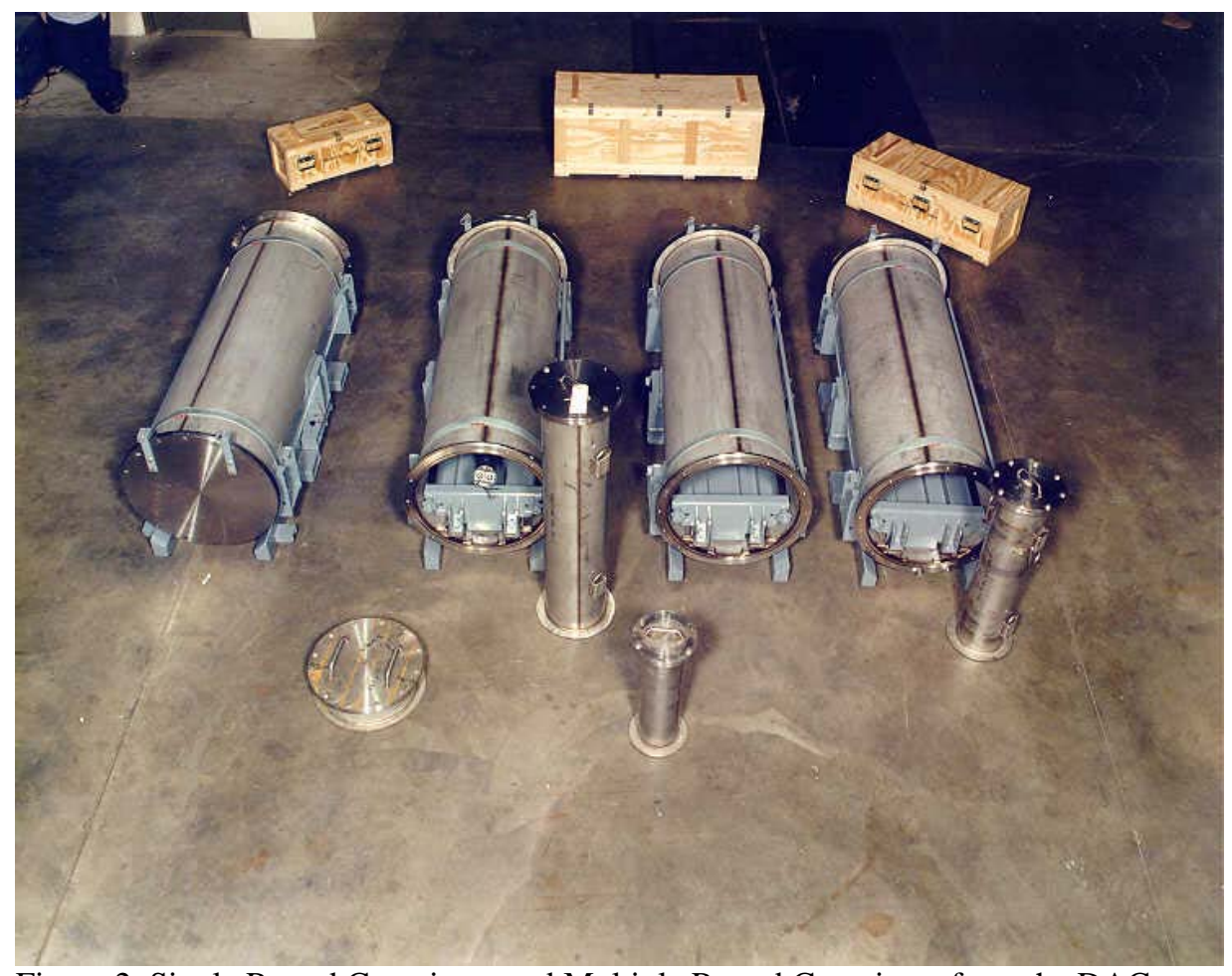

Figure 2. Single Round Containers and Multiple Round Containers from the DAC. 


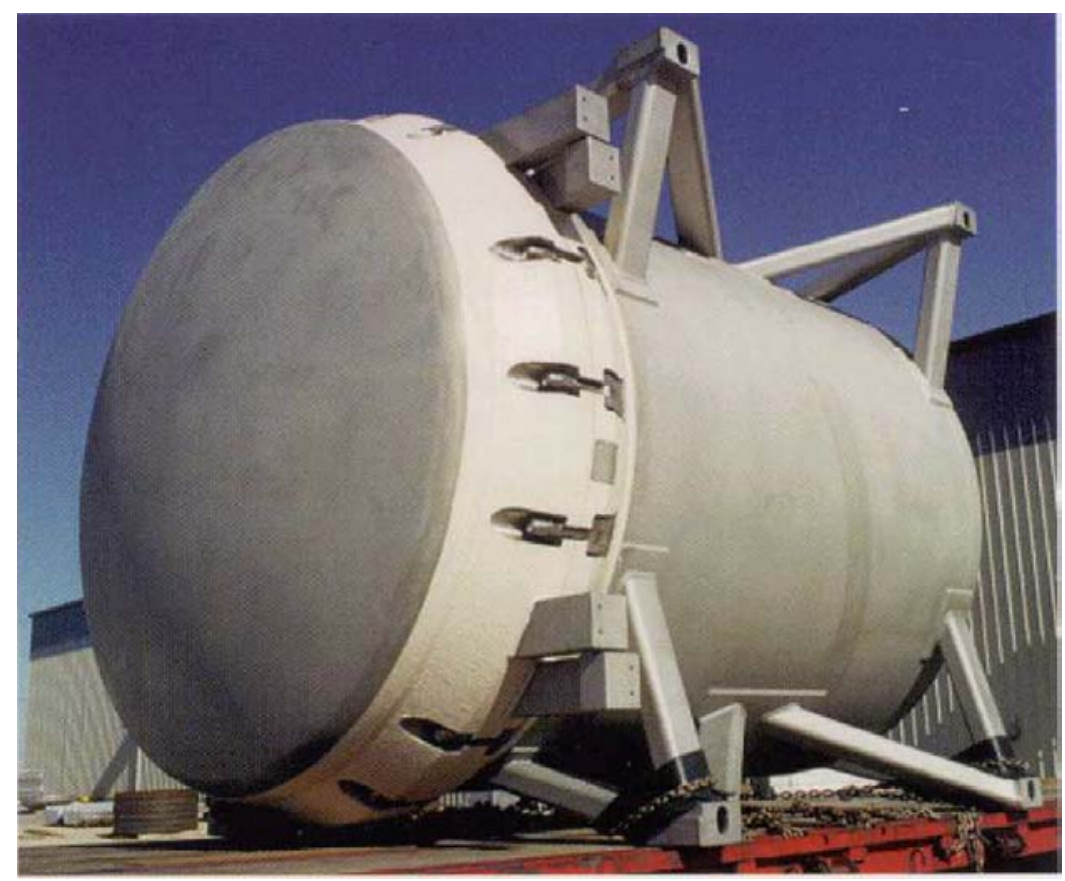

Figure 3. On-Site Container.

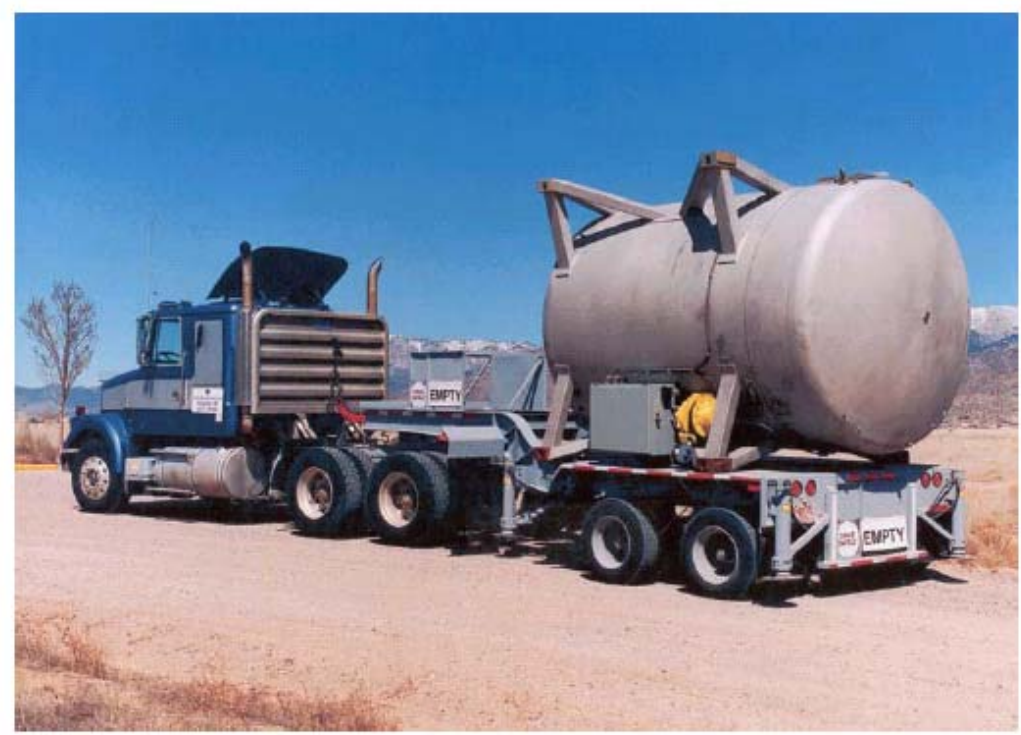

Figure 4. Enhanced On-site Container. 


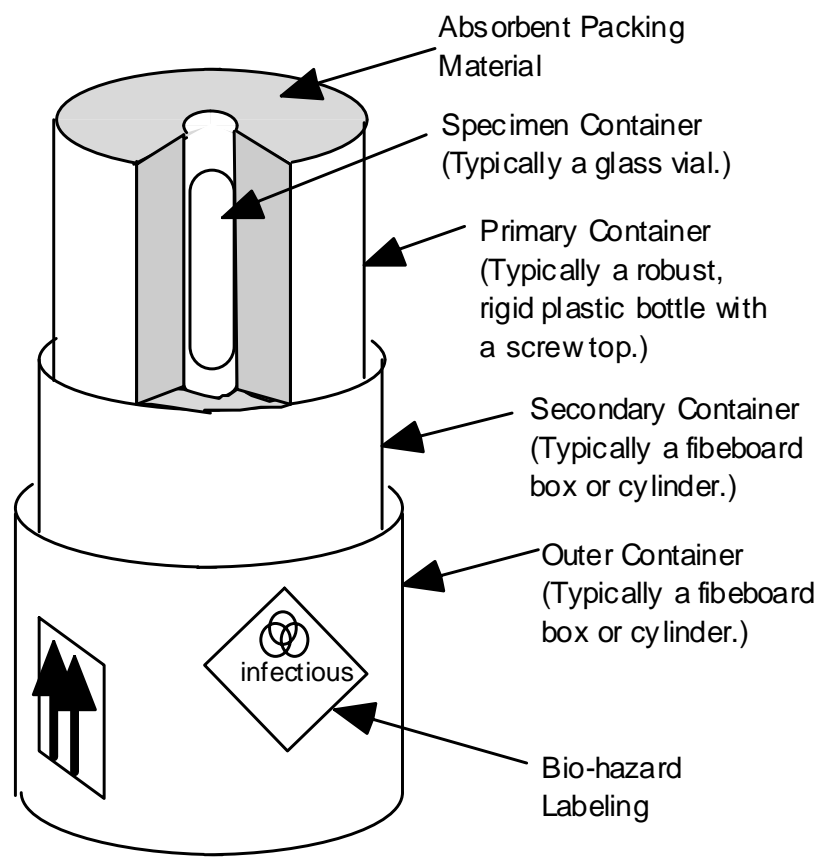

Figure 5. Typical Package for Infectious Substances 